\title{
ANALISIS SISTEM E-LOGISTIC EKSPOR IMPOR
}

\author{
Denny Riandhita Ariep Permana \\ dennyrian76@gmail.com
}

\begin{abstract}
ABSTRAK
United Parcel Service (UPS) merupakan salah satu perusahaan global yang bergerak di bidang jasa pengiriman barang keluar negeri (export-Import) menggunakan moda transportasi udara. UPS adalah pemimpin global dalam logistik, menawarkan banyak sekali solusi termasuk pengangkutan paket dan pengapalan, fasilitasi perdagangan internasional, dan penggunaan teknologi maju untuk mengelola dunia bisnis secara lebih efisien. Berdasarkan data yang dikeluarkan BPS mengenai jumlah ekspor-impor di Indonesia membuat banyak perusahaan freight forwarder, yang berskala nasional maupun internasional berdiri di Indonesia. Freight forwarder adalah perusahaan yang menjadi perantara antara pengirim barang (shipper) dan penerima barang (consignee). Sesuai dengan regulasi dari Negara Indonesia, UPS bekerjasama dengan PT Cardig mendirikan PT UPS Cardig International untuk mengakomodir kegiatan eksport-import yang ada di Indonesia. PT UPS Cardig International (UCI) dalam melaksanakan kegiatan operationalnya menggunakan e-logistic. Mulai dari pengiriman eksport sampai import selalu terintegrasi dengan sistem e-logistic. Penggunaan sistem ini tentu tidak terlepas dari masalah eror, perubahan system dan perubahan regulasi pemerintah. Masalah itu bisa hadir dari internal maupun eksternal perusahaan. Analisis SWOT dilakukan untuk membantu dan mencoba memberikan solusi strategi kepada PT UPS Cardig International (UCI).
\end{abstract}

Kata kunci: E-logistic, Ekspor, Impor, Analisis SWOT, Kekuatan, Kelemahan,Peluang, Ancaman.

\section{PENDAHULUAN}

\section{Latar Belakang}

Sistem transportasi merupakan salah satu bidang perekonomian nasional yang sangat berkembang saat ini khususnya dibidang transportasi udara, karena transportasi udara mampu memindahkan orang ataupun barang dari satu tempat ke tempat lainnya dalam waktu yang relatif singkat. Pergerakan penumpang dan atau barang pun kian meningkat seiring dengan berkembangnya bisnis transportasi udara. Dengan menggunakan moda transportasi udara, penumpang dapat melakukan perpindahan dengan waktu yang cepat begitu pula pada pengiriman barang trutama pada barang yang bersifat urgent.
Perusahaan yang tidak mampu menciptakan inovasi baru dapat dipastikan akan sulit memenangkan persaingan di dunia global. Perusahaan-perusahaan yang ada membutuhkan pula strategi bersaing yang handal dan berorientasi ke depan, dimana perlu adanya penyusunan strategi yang matang dan tidak main-main. Perusahaan harus memahami apa yang diinginkan konsumen saat ini dan untuk masa mendatang. Jadi, sukses dan gagalnya suatu perusahaan sangat bergantung kepada keunggulan bersaing yang dimiliki oleh perusahan tersebut. 
Pemanfaatan sistem Electronic Logistic (E-Logistik) yang baik akan mampu membuat Industri logistik makin efisien, sehingga perusahaan yang bergerak di bidang jasa pengiriman akan mampu memberikan layanan yang baik kepada pelanggannya. Tak hanya itu, program E-Logistik juga akan mampu menolong perusahaan jasa pengiriman dalam memberikan kepastian terhadap jasa pengiriman barang.

Dengan teknologi informasi yang menyertainya, layanan e-Logistik dipastikan akan mampu memberikan jaminan kepastian yang lebih baik kepada pelanggan. Karena itu, layanan e-Logistik sangat berguna untuk memberikan service level yang excellent buat pelanggan. Tujuan dari sistem ini adalah memberikan solusi untuk menumbuhkan industri logistik, mengingat logistik menjadi salah satu struktur penting dari kegiatan ekonomi.

Pada Negara berkembang seperti Indonesia, kegiatan ekspor sangatlah menjadi prospek yang baik bagi perkembangan ekonomi nasional. Itu dapat dilihat dari meningkatnya volume ekspor Indonesia pada Agustus 2015 meningkat 10,79 persen dibanding Juli 2015, yaitu dari US $\$ 11.465,8$ juta menjadi US $\$ 12.702,8$ juta. Sementara itu, dibandingkan dengan Agustus 2014, ekspor menurun 12,28 persen.

Peningkatan ekspor Agustus 2015 disebabkan oleh meningkatnya ekspor migas 7,67 persen dari US $\$ 1.421,8$ juta menjadi US $\$ 1.530,8$ juta, demikian juga ekspor nonmigas naik 11,23 persen, yaitu dari US $\$ 10.044,0$ juta menjadi US\$11.172,0 juta. (BPS, 2015). Ditengah terus meningkatnya ekspor di Indonesia, ini juga dibarengi dengan terus mening- katnya impor di indonesia. Tentu saja ini akan membuat industri asli Indonesia harus lebih keras dalam membuat inovasi dari barang daganganya. Dapat dilihat nilai impor Indonesia Agustus 2015 mencapai US\$12,27 miliar atau naik 21,69 persen apabila dibandingkan Juli 2015. Akan tetapi turun 17,06 persen jika dibandingkan Agustus 2014. (BPS,2015).

\section{Rumusan Masalah}

Berdasarkan latar belakang masalah yang diatas maka dibuat rumusan masalah apa saja yang terkait e-logistic di PT UPS Cardig International.

1. Bagaimana sistem e-logistic bekerja pada PT UPS Cardig International?

2. Bagaimana kesiapan PT UPS Cardig International terhadap kebijakan yang dikeluarkan pemerintah bagi kegiatan bisnis?

3. Bagaimana Strategi PT UPS Cardig International dalam menghadapi market dan competitor di Indonesia ?

4. Bagaimana langkah yang diambil PT UPS Cardig International untuk terus berkembang?

\section{Ruang Lingkup}

Masalah yang dibahas pada tesis ini adalah bagaimana pemanfaatan sistem elogistic, masalah yang dihadapi pada sistem e-logistic. Selain itu bagaimana strategi bisnis PT UPS Cardig International dalam memanfaatkan berkembangnya e-logistic dan munculnya pesaing. Analisis sistem ini dilakukan pada lingkungan operasional. Analisis yang dilakukan menggunakan analisis swot dan matriks IFAS dan EFAS.

\section{Tujuan Penulisan}

Berdasarkan rumusan masalah dan ruanglingkup masalah yang dibuat maka ditentukan tujuan dari penulisan ini sebagai berikut: 
1. Menganalisis sistem e-logistic pada PT UPS Cardig International

2. Menganalisis strategi bisnis yang digunakan PT UPS Cardig International

3. Memberikan pandangan untuk pengambilan strategi bisnis kedepanya terkait kebijakan pemerintah terhadap ekspor-impor

4. Menganalisis sebaran market place dan pesaing dari PT UPS Cardig International

5. Menganalisis kekurangan dan kelebihan dari PT UPS Cardig International

\section{Manfaat Penulisan}

Penelitian yang dilakukan pada penulisan tesis ini memiliki beberapa kegunaan, adapun kegunaan tersebut diantaranya :

1. Kegunaan Praktis

Bagi PT UPS Cardig International hasil penelitian ini diharapkan dapat membantu perusahaan dalam mengembangkan bisnis di masa yang akan datang. Selain itu dapat membantu dalam pemecahan masalah jika terjadi pada sistem yang berjalan

2. Kegunaan Akademis

Penelitian ini diharapkan dapat memperdalam kajian teori mengenai sistem e-logistic dan managemen logistic serta dapat dikembangkan di masa yang akan datang.

\section{TINJAUAN PUSTAKA}

Analisis Sistem Informasi

Analisis Sistem adalah penguraian suatu sistem informasi yang sudah utuh kedalam bagian-bagian komponennya dengan tujuan dapat menidentifikasi dan menevaluasi berbagai macam permasalahan maupun hambatan yang terjadi pada sistem sehingga nantinya dapat dilakukan perbaikan atau pengembangan

\section{Tujuan Analisis Sistem}

Tujuan analisis sistem yang utama adalah mengidentifikasi dan mengevaluasi berbagai macam permasalahan maupun hambatan yang terjadi. selain itu juga ada beberapa tujuan dari analisis sistem sebagai berikut:

1. Memberikan pelayanan kebutuhan informasi kepada fungsi manajerial di dalam pengendalian pelaksanaan kegiatan operasional perusahaan

2. Membantu para pemngambil keputusan

3. Mengevaluasi sistem yang telah ada

4. Merumuskan tujuan yang ingin dicapai berupa pengolahan data maupun pembuatan laporan baru

5. Menyusun suatu tahap rencana pengembangan sistem

Yang perlu diperhatikan oleh Analisis Sistem

6. Mempelajari permasalahan yang ada secara terinci

7. Menentukan pendekatan yang akan digunakan dalam memecahkan masalah

8. Membuat suatu pertimbangan apakah perlu atau tidak menggunakan cara komputerisasi.

9. Langkah langkah dalam Pengerjaan Analisis sistem

10. Mengidentifikasi masalah

11. Mengidentifikasi penyebab masalah

12. Analisis sistem

13. Mengidentifikasi solusi dari masalah

14. Analisis Kebutuhan

15. Mengidentifikasi data apa dan proses apa yang dibutuhkan pada sistem baru.

16. Menentukan kebutuhan fungsional dan non-fungsional dari sistem baru 


\section{Analis system}

analis sistem adalah orang yang mempunyai kemampuan untuk menganalisis sebuah sistem, memilih alternatif pemecahan masalah dan menyelesaikan masalah tersebut dengan menggunakan computer.

Adapun beberapa fungsi dari sistem analis, yang diantaranya meliputi:

1. Dapat menidentifikasikan berbagai masalah dari pemakai (user).

2. Menentukan secara jelas mengenai sasaran yang harus dicapai untuk dapat memenuhi kebutuhan pemakai.

3. Dapat memilih metode alternatif dalam memecahkan masalah pada sistem.

4. Dapat merencanakan maupun menerapkan rancangan sistem sesuai dengan apa yang diinginkan pemakai.

\section{Pengertian E-Business}

E-business adalah kegiatan bisnis yang dilakukan secara otomatis dengan memanfaatkan teknologi elektronik seperti komputer dan internet. E-business memungkinkan suatu perusahaan untuk berhubungan dengan sistem pemrosesan data internal dan eksternal secara lebih efisien dan fleksibel. Contoh dari ebusiness misalnya pembelian barang secara online melalui www.tokopedia.com. Dari proses pemesanan barang, konfirmasi pembayaran, hingga konfirmasi bahwa pengiriman barang tersebut sudah sampai kepada customer dilakukan secara elektronik. E-business memiliki karakteristik tujuan yang sama dengan bisnis secara konvensional, hanya saja ebusiness memiliki cakupan yang berbeda. Bisnis mengandalkan pertemuan antar pebisnis seperti halnya rapat ditempat khusus, atau sekadar untuk berkenalan dengan partner bisnis, sedangkan ebusiness mengandalkan media internet sebagai sarana untuk memperoleh tujuannya. Dalam kegiatan e-business, ada lima kemungkinan bentuk hubungan bisnis berdasarkan transaksinya, yaitu : Business to Business (perdagangan antar pelaku usaha bisnis) Business to Consumer (perdagangan antar pelaku usaha bisnis dengan konsumen) Consumer to Consumer (perdagangan antar konsumen yang satu dengan konsumen yang lain) Consumer to Business (perdagangan antar konsumen dengan pelaku bisnis atau perusahaan) Intrabusiness e-business (perdangan dalam lingkup intranet perusahaan yang melibatkan pertukaran barang, jasa, dan informasi( Nof. Shimon dan Ceroni. Jose, 2015). Sasaran dari e-business adalah pasar atau market. Menurut Forrester Research, telah terjadi perkembangan yang sangat fantastis terhadap jumlah komputer yang terhubung dalam internet, termasuk penggunanya. E-business market ini menyimpan peluang omset yang besar yang dapat diperebutkan oleh para pebisnis.

Tahapan E-business

Ada empat tahap pemanfaatan jaringan komputer dan internet untuk tujuan e-business, di mana terjadi transformasi perusahaan tradisional ke ebusiness (Jen-Yao. 2015), diantaranya sebagai berikut:

1. Mendayagunakan komputer

2. Mendayagunakan jaringan dan internet (seperti email, chat messanger, IRC)

3. Membangun dan mendayagunakan web

4. E-commerce

Jadi dapat disimpulkan bahwa pengertian e-commerce dan e-business 
apabila tidak dipahami terlebih dahulu akan membuat pembahasan tentang hal tersebut menjadi tidak sistematis. Hal ini dikarenakan kebingungan dalam menentukan istilah yang paling cocok untuk mewakili konsep perdagangan dengan sarana elektronik. Perbedaan yang mendasar antara e-commerce dan ebusiness adalah bahwa tujuan e-commerce berorientasi pada bagaimana memperoleh keuntungan, sedangkan e-business berorientasi pada kepentingan jangka panjang dan sifatnya abstrak seperti kepercayaan konsumen, pelayanan terhadap konsumen, peraturan kerja, relasi antar mitra bisnis, dan penanganan masalah social lainnya. Selain dari perbedaan yang dimiliki oleh keduanya, ternyata keduanya juga memiliki persamaan tujuan yaitu memajukan perusahaan menjadi perusahaan yang lebih besar dari sebelumnya.

\section{Pengenalan Logistik}

Kata logistik berasal dari bahasa

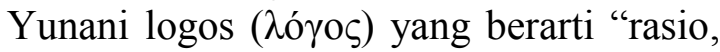
kata, kalkulasi, alasan, pembicaraan, orasi". Kata logistik memiliki asal kata dari Bahasa Perancis loger yaitu untuk menginapkan atau menyediakan. Kegunaan asalnya untuk menjelaskan ilmu dari pergerakan, suplai \& perawatan dari pasukan militer di lapangan. Nantinya digunakan untuk mendeskripsikan manajemen arus barang di sebuah organisasi, dari barang mentah menjadi barang jadi.

Pegertian lain logistik adalah proses pengelolaan dari pada pemindahan dan penyimpanan barang dan infomasi terkait dari sumber pengadaaan ke konsumen akhir secara efektif dan efisien.

Manajemen logistik merupakan bagian dari rantai pasokan atau (supply chain management) yang merencanakan, melaksanakan dan mengendalikan secara efektif dan efisien, aliran dan penyimpanan dari barang dan jasa serta informasi terkait dari titik (tempat) asal ke titik (tempat) konsumsi yang bertujuan untuk memenuhi kebutuhan pelanggan. (Chen. Hanlin dan Kong. Lingxiang, 2008).

Sistem logistik merupakan interaksi yang terintegrasi dari berbagai sub sistem dalam bidang logistik dimana terjadi keterkaitan antar peran dan antar fungsi dan antar bagian yang diarahkan untuk mencapai sasaran yang menyeluruh. sistem logistik mempunyai masukan berupa sumber daya manusia seperti uang, mesin, material,jasa, manjemen,metoda, dan sebagainya.

\section{Managemen Logistik}

Manajemen logistik adalah bagaimana mendisain dan mengurus suatu sistem untuk mengawasi arus dan penyimpanan yang strategis bagi material, suku cadang dan barang jadi agar dapat diperoleh manfaat maksimum bagi organisasi.

\section{Tujuan umum}

a. Tujuan Operasional : agar tersedia barang atau bahan dalam jumlah yang tepat dan mutu yang memadai

b. Tujuan keuangan Merupakan oprasional dapat terlaksana dengan biaya yang serendah-rendahnya.

c. Tujuan pengamanan agar persediaan tidak terganggu dari kerusakan, pemborosan, pencucian dan pengusutan yang tidak wajar.

\section{Tujuan khusus}

Mendukung efektifitas dan efisiensi dalam setiap upaya pencapaian tujuan organisasi.

\section{Fungsi Manajemen Logistik}


Menurut Syafrudin (2009), Fungsi logistik dapat disusun dalam bentuk skema siklus kegiatan logistik sebagai berikut :

Masing-masing fungsi logistik tersebut saling berhubungan satu dengan yang lain. Untuk itu kita bahas satu persatu fungsi logistik tersebut.

1. Fungsi Perencanaan

2. Fungsi Penganggaran

3. Fungsi Pengadaan

4. Fungsi Penyimpanan

5. Fungsi Penyaluran (Distribusi)

6. Fungsi Penghapusan

7. Fungsi Pengendalian

\section{Pengertian E-Logistik}

E-logistik merupakan kegiatankegiatan bisnis yang menyangkut konsumen (consumers), manufaktur (manufactures), service providers dan pedagang perantara (intermediaries) dengan menggunakan jaringan-jaringan komputer (komputer networks) yaitu internet.(PPM dan Asosiasi Logistic Indonesia. 2011).

E-logistik menjadi suatu bagian penting dalam dunia bisnis saat ini. Elogistik tidak hanya bicara tentang pergudangan tapi juga pelayanan terintegrasi oleh sistem. Mulai dari pergudangan atau istilahnya track and trace shipment hingga ke pengiriman ke tangan konsumen yang lebih efektif. Layanan ini merupakan layanan outsourcing end to end yang dimulai dari menyediakan infrastruktur, data centre, aplikasi, perangkat, operasi bisnis (business operation) dan terakhir disaster recovery sistem, semua itu berbasis real time untuk semua transaksi pembayaran dan penagihan.

Keuntungan E-logistik Pemanfaatan aplikasi Electronic Logistic (elogistik) yang baik akan mampu membuat Industri logistik makin efisien, sehingga perusahaan yang bergerak di bidang jasa pengiriman akan mampu memberikan layanan yang baik kepada pelanggannya. Tak hanya itu, program e-logistik juga akan mampu menolong perusahaan jasa pengiriman dalam memberikan kepastian terhadap jasa pengiriman barang. Pemanfaatan TI e-logistik dapat dipakai oleh perusahaan-perusahaan yang menggunakan sistem logistik, sehingga logistik menjadi lebih maju dan efisien bagi perusahaan tersebut. Selain itu sistem ini juga dapat mengontrol masalah tracking pengiriman barang sehingga suatu perusahaan dapat memberikan jaminan terhadap barang transaksi. Dengan teknologi informasi yang menyertainya, layanan e-logistik dipastikan akan mampu memberikan jaminan kepastian yang lebih baik kepada pelanggan. Karena itu, layanan e-logistik sangat berguna untuk memberikan service level yang excellent buat pelanggan. Tujuan dari sistem ini adalah memberikan solusi untuk menumbuhkan industri logistik, mengingat logistik menjadi salah satu struktur penting dari kegiatan ekonomi.

\section{Penerapan E-logistic di Perusahaan Pengiriman Barang (Ekspor-Impor)}

Perusahaan jasa pengiriman barang saat ini sudah sangat berkembang. Perkembangannya sudah cepat apalagi dengan adanya pengaruh IT dalam proses bisnisnya. Pengaruh IT dalam perusahaan jasa pengiriman sangat bermanfaat, misal membuat pengriman barang menjadi cepat atau memudahkan dalam proses.

Berikut adalah beberapa penerapan elogistic pada perusahaan jasa:

1. Website Trace \& Tracking

2. Website Pickup

3. GPS

4. Scanner 


\section{Kuesioner}

Kuesioner adalah suatu teknik pengumpulan informasi yang memungkinkan analis mempelajari sikap-sikap, keyakinan, perilaku, dan karakteristik beberapa orang utama di dalam organisasi yang bisa terpengaruh oleh sistem yang diajukan atau oleh sistem yang sudah ada.

Dengan menggunakan kuesioner, analis berupaya mengukur apa yang ditemukan dalam wawancara, selain itu juga untuk menentukan seberapa luas atau terbatasnya sentimen yang diekspresikan dalam suatu wawancara.

Penggunaan kuesioner tepat bila :

1. Responden (orang yang merenpons atau menjawab pertanyaan) saling berjauhan.

2. Melibatkan sejumlah orang di dalam proyek sistem, dan berguna bila mengetahui berapa proporsi suatu kelompok tertentu yang menyetujui atau tidak menyetujui suatu fitur khusu dari sistem yang diajukan.

3. Melakukan studi untuk mengetahui sesuatu dan ingin mencari seluruh pendapat sebelum proyek sistem diberi petunjuk-petunjuk tertentu.

4. Ingin yakin bahwa masalah-masalah dalam sistem yang ada bisa diidentifikasi dan dibicarakan dalam wawancara tindak lanjut.

\section{Analisis SWOT}

Analisis SWOT merupakan suatu bentuk analisis yang digunakan oleh manajemen perusahaan atau organisasi yang sistematis dan dapat membantu dalam usaha penyusunan suatu rencana yang matang untuk mencapai tujuan perusahaan atau organisasi tersebut. Baik tujuan tersebut untuk tujuan jangkan panjang maupun tujuan jangka pendek. Selain itu, Analisis SWOT juga dapat diartikan sebagai sebuah bentuk analisa situasi dan kondisi yang bersifat deskriptif (memberi suatu gambaran) tentang sebuah perusahan atau oraganisasi. Analisa ini menempatkan situasi dan kondisi sebagai sebagai faktor yang di jadikan masukan. Dan kemudian masukan tersebut dikelompokkan sesuai kontribusinya masing-masing. SWOT merupakan singkatan dari Strength Weaknesses Opportunities Threats. Yang artinya Strength (kekuatan), Weaknesses (kelemahan), Opportunities (Peluang), Threats (hambatan).

\section{Manfaat Analisis SWOT}

Metode analisis SWOT merupakan metode analisis yang paling dasar dalam melakukan analisis strategi, yang bermanfaat untuk mengetahui suatu permasalahan ataupun suatu topik dari 4 empat sisi yang berbeda. Hasil dari analisis ini biasanya berupa arahan ataupun rekomendasi untuk mempertahankan kekuatan dan untuk menambah keuntungan suatu perusahaan atau organisasi dari segi peluang yang ada, sambil mengurangi kekurangan yang dimiliki dan juga menghindari berbagai ancaman yang terjadi.

Analisis ini akan dapat digunakan untuk membantu melihat sisi-sisi yang terabaikan atau tidak terlihat dari sebuah perusahaan atau organisasi. Berdasarkan uraian di atas tadi, analisis SWOT adalah instrumen yang bermanfaat dalam melakukan analisis strategi dalam manajemen perusahaan atau organisasi . Analisis ini berperan sebagai alat untuk meminimalisir kelemahan atau kekurangan yang terdapat dalam suatu perusahaan atau organisasi serta menekan dampak dari ancaman yang timbul dan harus dihadapi. 


\section{Analisis Faktor Strategis Eksternal}

Analisis faktor strategis eksternal difokuskan pada kondisi yang ada dan kecenderungan yang muncul dari luar, tetapi dapat memberi pengaruh kinerja organisasi. Setelah mengetahui faktorfaktor strategi eksternal, selanjutnya susun tabel faktor-faktor Strategis Eksternal (External Strategic

Factors Analysis Summary/EFAS)

\section{Analisis Faktor Strategis Internal}

Analisis faktor strategis internal adalah analisis yang menilai prestasi/ kinerja yang merupakan faktor kekuatan dan kelemahan yang ada untuk mencapai tujuan organisasi. Seperti halnya pada
Analisis Faktor Strategis Eksternal, maka dengan cara yang sama menyusun tabel Faktor-faktor Strategis Internal (Internal Strategic Factors Analysis Summary/IFAS)

\section{Metode Penelitian Kerangka Penelitian}

Analisis sistem E-Logistic di PT UPS Cardig International akan dilakukan secara bertahap. Adapun tahapan tahapanya dimulai dari pengumpulan data, pengolahan data, pembuatan kuesioner, pengambilan sample kuesioner, dan pengolahan data kuesioner, yang disajikan dalam diagram sebagai berikut :

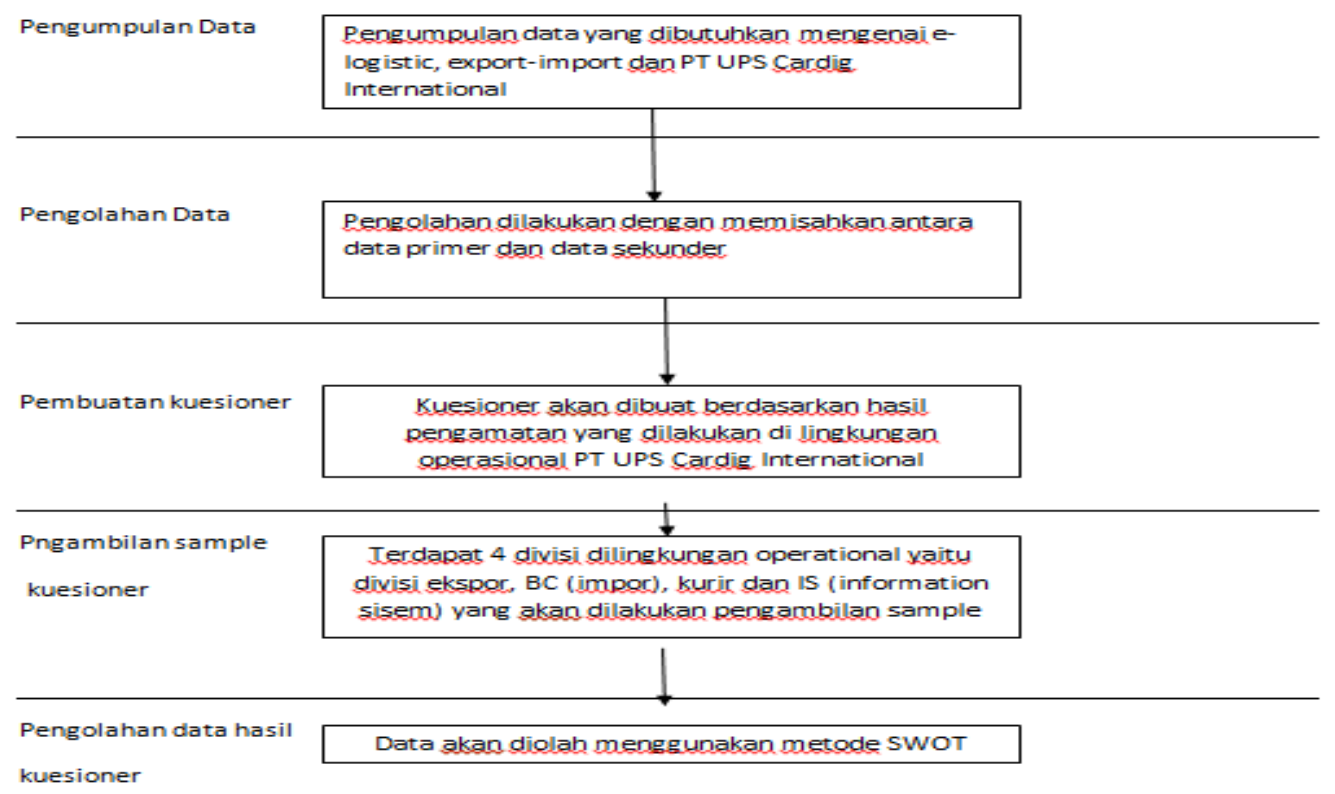

Gambar 3.1 Diagram Kerangka Penelitian

\section{Jenis dan Teknik Pengumpulan Data}

Jenis penelitian ini adalah penelitian kuantitatif yang menekankan pada analisis sistem e-logistic terhadap kegiatan ekspor-impor di PT UPS Cardig international menggunakan metode SWOT. Analisis ini diharapkan dapat menghasilkan rekomendasi sistem yang baik kedepanya. Berdasarkan sifat dan sumber datanya data yang digunakan, yaitu:

\section{Data primer}

Data mentah yang didapat dari objek penelitian. Data jenis ini akan diolah 
dengan teknik pengolahan tertentu agar dapat digunakan dalam langkahlangkah analisis.yang termasuk dalam data primer antara lain data mengenai faktor-faktor internal kekuatan dan kelemahan dari sistem e-logistic di PT UPS Cardig International serta data mengenai faktor-faktor eksternal peluang dan ancaman. Sumber data ini didapat dari pengguna sistem, pengelola gudang, dan pegawai di lingkungan operational.

\section{Metode Pengumpulan Data}

Dalam pengumpulan data dilakukan di lingkungan PT UPS Cardig international. Pengumpulan data dilakukan selama 2 minggu. Untuk pengumpulan data yang relevan dan lengkap akan digunakan metode pengumpulan data sebagai berikut:

\section{Metode Dokumentasi}

Metode dengan melakukan pengambilan data secara langsung dengan melakukan pencatatan atas dokumendokumen yang ada pada PT UPS Cardig International. Metode ini digunakan terutama untuk mengambil data-data sekunder.

\section{Metode Angket atau Kuesioner}

Angket atau kuesioner adalah teknik pengumpulan data melalui formulir yang berisi pertanyaan-pertanyaan yang diajukan secara tertulis pada seseorang atau sekumpulan orang untuk mendapatkan jawaban atau tanggapan dan informasi yang diperlukan oleh peneliti (Mardalis: 2008: 66). Kuesioner ini digunakan untuk memperoleh data tentang metode SWOT pada PT UPS Cardig International. Kuesioner akan disebar ke 5 divisi operasional yaitu divisi ekspor, BC (impor), kurir, IS dan CSTC. Dalam penyebaran kuesioner diambil sampel sebanyak 20 koresponden dengan rincian 4 kuesioner pada divisi ekspor (1 supervisor dan 3 staff), 4 kuesioner pada divis impor (1 supervisor dan 3 staff), 4 kuesioner pada kurir dan 4 kuesioner pada divisi CSTC (4 staff).

\section{Metode Wawancara}

Metode ini dilakukan dengan melakukan komunikasi untuk mendapatkan data-data dari perusahaan. Wawancara dilakukan kepada manager dan supervisor sebagai level managemen. Data yang dikumpulkan berupa studi kasus yang sering terjadi atau masalah yang terjadi dalam kegiatan operasional.

\section{Metode Observasi}

Metode ini dilakukan dengan pengamatan secara langsung objek penelitian. Metode ini digunakan untuk mengetahui secara langsung sistem teknologi yang ada di PT UPS Cardig International. Sebagai contoh observasi yang dilakukan dengan ikut megantar paket kiriman ke costumer.

\section{Metode Studi Pustaka}

Pengumpulan data atau informasi dari buku-buku yang berhubungan dengan penelitian dan bertujuan untuk menemukan teori, konsep, dan variable lain yang dapat mendukung penelitian. Data atau informasi yang dikumpulkan melalui refrensi-refrensi, jurnal dan artikel di perpustakaan ataupun internet.

\section{Variabel Penelitian}

Variabel penelitian adalah suatu atribut atau sifat atau nilai dari orang, obyek atau kegiatan yang mempunyai variasi tertentu yang ditetapkan oleh peneliti untuk dipelajari dan kemudian 
ditarik kesimpulannya (Sugiyono, 2012: 61).

Pada penelitian ini digunakan satu variable yaitu variable bebas. variabel bebas adalah "Merupakan variabel yang mempengaruhi atau yang menjadi sebab perubahannya atau timbulnya variabel dependen (terikat)" Sugiyono (2011:61). Variable bebas yang digunakan dalam penelitian ini adalah faktor-faktor internal dan eksternal sistem e-logistic di PT UPS Cardig International.

\section{Faktor Internal}

Faktor-faktor internal yang termasuk dalam sistem elogistic PT UPS Cardig International yaitu:

1. Sumber Daya Manusia Sumber daya Manusia merupakan factor penting dalam kemajuan suatu sistem informasi. Setiap karyawan harus mempunyai kemampuan yang dibutuhkan oleh PT UPS
Cardig International dalam pemanfaatan dan pengembangan sistem Elogistic.

2. Jaringan

Setiap perangkat computer di wilayah operational PT UPS Cardig International menggunakan kabel lan untuk menghubungkan internet. Jaringan internet harus terhubung pada setiap perangkat e-logistic dikarenakan setiap kinerja harus update secara real dan cepat.

3. Perangkat Keras

Perangkat keras yang digunakan tergantung spesifikasi dan kegunaan dari perangkat keras tersebut. Pada setiap divisi perangkat computer yang digunakan berspesifikasi sebagai tersebut:

System Information

Current Date/Time: Wednesday, April 13, 2016, 11:57:43 PM

Computer Name: WKSP00058ETD

Operating System: Windows 7 Professional 64-bit (6.1, Build 7601)

Language: English (Regional Setting: English)

System Manufacturer: HewlettPackard

System Model: HP EliteDesk 705 G1 SFF

BIOS: Default System BIOS

Processor: AMD A4PRO-7300B APU with Radeon HD Graphics (2 CPUs), $3.8 \mathrm{GHz}$

Memory: 8192MB RAM

Page fle: 1939MB used, 12871MB available

DirectX Version: Directx 11

\section{Gambar 3.2 Spesifikasi Komputer}


4. Armada

Dalam proses pengiriman barang PT UPS Cardig International memerlukan armada seperti mobil, truk dan sepeda motor. Armada yang baik dan prima akan membantu dalam proses pengriman barang ke pelanggan, maka dari itu armada akan dilakukan service rutin sebagai salah satu pelayanan yang baik.

5. Aplikasi

Aplikasi yang digunakan oleh PT UPS Cardig International merupakan aplikasi global. Aplikasi ini digunakan oleh semua cabang UPS (Unite Parcel Service) di seluruh dunia. Beberapa aplikasi yang digunakan yaitu:

1. UDC (United Data Capture)

2. IDC (International Data Capture)

3. Sistem informasi Mainframe

4. Sistem Billing

\section{Faktor eksternal}

Faktor-faktor eksternal yang mempengaruhi sistem E-logistic di PT UPS Cardig International, yaitu:

1. Persaingan

Persaingan dengan perusahaan multinasional yang bergerak dibidang yang sama seperti DHL, FEDEX dan TNT masih menjadi persaingan utama maka dari itu PT UPS cardig International terus mengembakan sistem informasi yang dimilikinya.

2. Kebijakan Pemerintah
Salah satu masalah yang dihadapi persuahaan multinasional atu perusahaan ekspor-impor adalah kebijakan pemerintah. Kebijakan pemerintah yang ketat dan sering berubahubah terhadap perusahaan asing menyebabkan terbatasnya bantuan yang bisa diberikan UPS pusat.

3. Hubungan dengan rekan bisnis PT UPS Cardig International dalam memajukan bisnisnya di Indonesia bekerja sama dengan beberapa perusahaan seperti TIKI JNE. Kerja sama ini dilakukan selain pengembangan bisnis juga untuk dapat membantu dalam pengiriman yang tidak terjangkau seperti ke daerah-daerah terpencil oleh PT UPS Cardig International.

4. Pendanaan

Dalam kegiatan bisnisnya PT UPS Cardig International mempunyai pendanaan yang cukup besar mulai dari kegiatan operasional, pengadaan item, dan perawatan hardware maupun armada dan lain-lain. Pada dasarnya pendanaan didapat dari hasil bisnis maupun bantuan dana dari pusat.

\section{Metode Analisis Data Analisis SWOT}

Analisis SWOT digunakan untuk menggambarkan kondisi dan mengevaluasi suatu masalah, proyek atau konsep berdasarkan faktor internal dan faktor eksternal yaitu Strength, Weakness, Oppurtunity, dan Threats. Metode sering digunakan dalam metode evaluasi bisnis untuk mencari strategi yang akan dilakukan. Analisis SWOT menggambar- 
kan situasi yang terjadi bukan sebagai pemecah masalah. Analisis SWOT akan membedah permasalahan sistem ELogistic ekspor-impor di PT UPS Cardig International yang terdiri dari empat factor, yaitu:

1. Kekuatan

2. Kelemahan

3. Peluang

4. Ancaman

Pendekatan Kualitatif Analisis SWOT
Pendekatan kualitatif matriks SWOT sebagaimana dikembangkan oleh Kearns menampilkan delapan kotak, yaitu dua paling atas adalah kotak faktor eksternal (Peluang dan Tantangan) sedangkan dua kotak sebelah kiri adalah faktor internal (Kekuatan dan Kelamahan). Empat kotak lainnya merupakan kotak isu-isu strategis yang timbul sebagai hasil titik pertemua antara faktor-faktor internal dan eksternal.

Tabel 3.1 Matriks SWOT Kearns

\begin{tabular}{|c|c|c|}
\hline INTERNAL & OPPORTUNITY & TREATHS \\
\hline STRENGTH & $\begin{array}{l}\text { Comparative } \\
\text { Advantage }\end{array}$ & $\begin{array}{l}\text { Mobilization } \\
\because \therefore \therefore \therefore \therefore\end{array}$ \\
\hline WEAKNESS & Divestmeint Investmien & $\begin{array}{l}\text { Dainage Contro } \\
\therefore \therefore \therefore \therefore \therefore \therefore \therefore\end{array}$ \\
\hline
\end{tabular}

HASIL DAN PEMBAHASAN

Hasil Analisis SWOT Sistem E-Logistic Identifikasi Faktor Strategis Lingkungan Internal

1. Kekuatan

Kekuatan merupakan kondisi yang menggambarkan kekuatan didalam perusahaan. Analisa SWOT terhadap Sistem e-logistic diidentifikasi factor strategis lingkungan internal.

\section{Kelemahan}

Kelemahan merupakan kondisi yang menggambarkan kelemahan didalam perusahaan. Kelemahan ini yang bisa menjadi kendala di waktu lama atau dekat jika tidak segera di antisipasi. Analisa SWOT terhadap Sistem e-logistic diidentifikasi faktor strategis lingkungan internal
Identifikasi Faktor Strategis Lingkungan Eksternal

\section{Peluang}

Peluang atau Kesempatan merupakan kondisi yang menggambarkan kemungkinan diluar perusahaan. Kemungkinan ini yang bisa membuat suatu perusahaan berkembang kedepanya. Perusahaan dapat berkembang jika perusahaan dapat memanfaatkan peluang sekecil apapun. Analisa SWOT terhadap Sistem e-logistic diidentifikasi factor strategis lingkungan internal.

\section{Ancaman}

Ancaman merupakan kondisi yang menggambarkan ancaman dari luar perusahaan. Ancaman ini yang bisa membuat suatu perusahaan merugi atau yang paling parah bangkrut jika tidak segera dicegah dan ditemukan solusinya. Ancaman yang didapat biasanya dari 
pesaing atau pelanggan dari perusahaan. Analisa SWOT terhadap Sistem e-logistic diidentifikasi factor strategis lingkungan internal

\section{Analisis Matriks SWOT}

Berdasarkan hasil yang didapat dari analisis internal dan eksternal maka hasilnya dapat dirangkum sebagai berikut:

1. Skor Total Kekuatan 8,98

Menunjukan bahwa faktor strategis seperti sumber daya manusia, jaringan, perangkat keras, armada dan aplikasi memberikan pengaruh penting terhadap internal faktor analisis strategi. Untuk mengetahui kekuatan dengan ukuran pembobotan nilainya 1 sampai dengan 4 dari segi pentingnya faktor tersebut dan ukuran rating bernilai 1 sampai dengan 4 dari segi kekuatanya. Perhitungan dilakukan dengan cara untuk menentukan rating pada tabel yaitu rating $=$ jumlah $/$ audience. Selanjutnya untuk menentukan skor dalah skor $=$ bobot $*$ rating, dimana bobot telah ditentukan berdasarkan kepentingan dari pertanyaan kuesioner. Dari perhitungan tersebut maka didapat hasil Kekuatan 8.98 .

2. Skor Total Kelemahan $-8,42$

Menunjukan bahwa faktor strategis seperti sumber daya manusia, jaringan, perangkat keras, armada dan aplikasi memberikan pengaruh penting terhadap internal faktor analysis strategy untuk mengetahui kelemahan dengan ukuran pembobotan nilainya 1 sampai dengan 4 dari segi pentingnya faktor tersebut dan ukuran rating bernilai -1 sampai dengan -4 dari segi kelemahanya. Perhitungan dilakukan dengan cara untuk menentukan rating pada tabel yaitu rating $=$ jumlah $/$ audience. Selanjutnya untuk menentukan skor dalah skor $=$ bobot $*$ rating, dimana bobot telah ditentukan berdasarkan kepentingan dari pertanyaan kuesioner. Dari perhitungan tersebut maka didapat hasil kelemahan -8.42 .

3. Skor Total Peluang 8,61

Menunjukan bahwa faktor strategis seperti persaingan, kebijakan pemerintah, hubungan dengan partner dan pendanaan memberikan pengaruh penting terhadap eksternal faktor analysis strategy untuk mengetahui peluang dengan ukuran pembobotan nilainya 1 sampai dengan 4 dari segi pentingnya faktor tersebut dan ukuran rating bernilai 1 sampai dengan 4 dari segi peluangnya. Perhitungan dilakukan dengan cara untuk menentukan rating pada tabel yaitu rating = jumlah / audience. Selanjutnya untuk menentukan skor dalah skor $=$ bobot $*$ rating, dimana bobot telah ditentukan berdasarkan kepentingan dari pertanyaan kuesioner. Dari perhitungan tersebut maka didapat hasil peluang 8.61 .

4. Skor Total Ancaman -8,26

Menunjukan bahwa faktor strategis seperti persaingan, kebijakan pemerintah, hubungan dengan partner dan pendanaan memberikan pengaruh penting terhadap eksternal faktor analysis strategy untuk mengetahui ancaman dengan ukuran pembobotan nilainya 1 sampai dengan 4 dari segi pentingnya faktor tersebut dan ukuran rating bernilai -1 sampai dengan -4 dari segi ancamanya. Perhitungan dilakukan dengan cara untuk menentukan rating pada tabel yaitu rating $=$ jumlah $/$ audience. Selanjutnya untuk menentukan skor dalah skor $=$ bobot $*$ rating, dimana bobot telah ditentukan berdasarkan kepentingan dari 
pertanyaan kuesioner. Dari perhitungan tersebut maka didapat hasil ancaman -8.26.

Dari hasil perhitungan diatas, di
dalam memerlukan penegasan dari adanya posisi dalm salib sumbu yaitu antara kekuatan dan kelemahan, maupun peluang dan ancaman yang semuanya digambarkan dalam garis-garis positif dan negative. Hal ini mengakibatkan, skor total kekutan tetap 8,98 , skor total kelemahan menjadi 8,42 sedangkan skor peluang 8,61 dan skor total ancaman menjadi- 8,26.

Dari analisis tersebut diatas bahwasanya faktor kekuatan lebih besar dari faktor kelemahan dan mempunyai faktor peluang yang besar dibandingkan ancaman. Oleh karena itu posisi sistem elogistic ekspor-impor berada pada kwadran 1 yang berarti sistem memiliki intern yang kuat dan sangat berpeluang untuk lebih berkembang.

Penentuan posisi sistem e-logistic ekspor-impor selanjutnya dicari koordinatnya. Untuk mencari koordinat, dapat dicari dengan cara sebagai berikut:

Koordinat Analisis Internal

(Skor total kekuatan - skor total kelemahan) : 2

$(8,98-8,42): 2=0.28$

Koordinat Analisis Eksternal

(Skor total peluang - skor total ancaman) : 2

$(8,61-8,26): 2=0,175$

Jadi titik koordinatnya terletak pada $(0,175 ; 0.28)$
Posisi SWOT Sistem E-Logistic EksporImpor

Posisi SWOT system e-logistic eksporimpor PT UPS Cardig International dapat digambarkan pada gambar 4.1

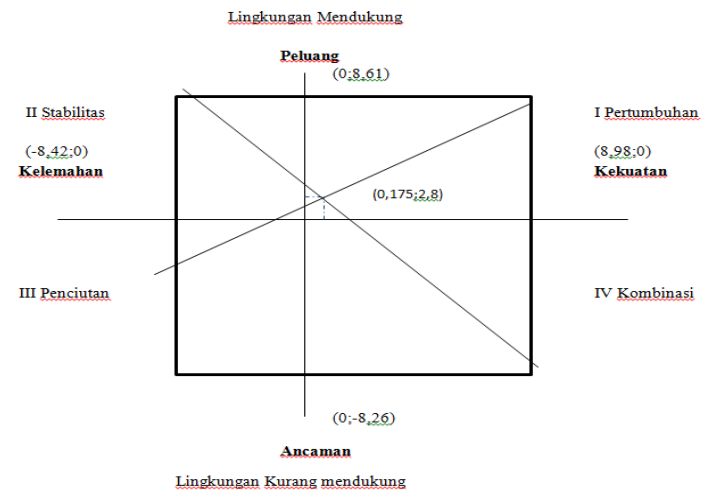

\section{Gambar 4.1 Posisi SWOT Sistem E- Logistic Ekspor-Impor}

Setelah diketahui titik pertemuan koordinat tersebut $(0,175 ; 0,28)$ maka posisi perusahaan terdapat pada kuadran I.

\section{KESIMPULAN DAN SARAN Kesimpulan}

Didapat kesimpulan berdasarkan pengolahan data kuesioner yang dilakukan kepada karyawan internal perusahaan serta melakukan beberapa analisis terhadap masing-masing dimensi kekuatan, kelemahan, peluang dan ancaman adalah kesimpulan yang baik untuk terus berkembangnya sistem e-logistic ekspor-impor PT UPS Cardig International. berdasarkan hasil tersebut didapat bahwa strategi yang digunakan yaitu strategi bersifat agresif, misalnya terus berkembang dan melebarkan market place dari perusahaan.

Berdasarkan hasil analisis SWOT yang terdiri dari lingkungan internal (kekuatan dan kelemahan) dan eksternal ( peluang dan ancaman) diadapatkan skor total kekuatan 8,98, skor total kelemahan - 
8,42 , skor total peluang 8,61 dan skor total ancaman $-8,26$.

Mengacu pada angka skor di atas dan berdasarkan matriks IFAS dan EFAS maka diperoleh pemahaman bahwa posisi system e-logistic ekspor-impor berada dalam keadaan yang menggambarkan kondisi internal yang baik dan kondisi eksternal yang mendukung sehingga titik koordinat pertemuan berada posisi pertumbuhan. Artinya PT UPS Cardig International dapat terus berkembang dan tumbuh yaitu bersifat growth strategi. Selain itu untuk memperlebar sayap bisnisnya PT UPS Cardig International harus memulai dari memperbaiki layanan servis yang sudah ada. Dengan meperbaiki layanan servis yang ada maka selanjutnya dengan menambah target pasar dari perusahaan. Dengan bertambahnya target pasar otomatis volume ekspor dan impor.

Terkait pesaing yang dihadapi PT UPS Cardig International seperti DHL, Fedex dan TNT. Maka PT UPS Cardig International harus memiliki inovasi dari segi layanan servis, armada maupun adanya diskon-diskon yang menarik bagi pelanggan. Jadi untuk terus berkembang PT UPS Cardig International harus mengembangkan sumber daya manusia, jaringan, hardware dan armada yang dimiliki oleh perusahaan.

Berdasarkan semua analisis yang dilakukan disimpulkan bahwa PT UPS Cardig International dapat mencapai visi dan misinya dalam 5 tahun kedepan yaitu menghubungkan semua orang didunia melalui jaringan logistic yang cerdas dengan menciptakan nilai, perubahan dan berinvestasi untuk berkembang. Visi dan misi tersebut terwujud dalam bagaimana PT UPS Cardig International bekerja yaitu empowering, growing and innovating together.

\section{Saran}

Saran untuk pengembangan sistem E-Logistic Ekspor-Impor yang dipunyai PT UPS Cardig International dapat merekrut SDM yang profesional dan terus meningkatkan kemampuan karyawan dengan pelatihan-pelatihan di bidang IT maupun Logistik. Melakukan kerjasama dengan vendor untuk melakukan pengembangan dari segi jaringan maupun server, dengan melakukan kerjasama dengan vendor maka system jaringan yang baik dan terstruktur dapat terwujud. Untuk pengembangan aplikasi dapat dibuat aplikasi mobile untuk melakukan pickup atau pemesanaan pengiriman ekspor maupaun impor.

Dalam kegiatan operationalnya yaitu pengiriman barang perusahaan diharapkan dapat menambah jumlah armada untuk mempercepat pengiriman sebagai penambahan service yang lebih baik bagi pelanggan. Untuk eksternal lingkungan diharapkan perusahaan terus mengembangkan pasarnya tidak hanya dibidang pengiriman namun bisa pengurusan dokumen. Perbaikan dari prasarana dan infrastruktur warehouse menjadi perhatian paling utama.

\section{DAFTAR PUSTAKA}

Chen. Hanlin dan Kong. Lingxiang. 2008. An Analysis on the Implementation of Electronic Supply Chain in International Trade. Integration and Innovation Orient to E-Society, Volume 1, pp 115-125

Elisabeth, Erly Farida, 2010. Perencanaan Strategis Sistem Informasi PD. Alom Jaya(AJ), Universitas Gunadarama E-Paper, pp, 1-15. 
Gartuna, Dhani \& Thalib, Farid, 2010. Analisis dan Rancangan Cetak Biru Pengembangan Infrastruktur Jaringan Teknologi Informasi dan Komunikasi Badan Litbang Pertanian, Universitas Gunadarama E-Paper,pp 1-13.

Ha. Soo-Cheol dan Choi. Jae-Eon. 2002. A model design of the Track \& Trace system for e-logistics. Operational Research, Volume 2, Issue 1, pp 5-15.

Holtgrave. David $\mathrm{R}$ dan Greenwald. Robert. 2016. A SWOT Analysis of the Updated National HIV/AIDS Strategy for the U.S. AIDS and Behaviour, Volume 20, Issue 1, pp $\underline{1-6}$

Juhardi, Ujang. Noersasongko, Edi, \& Sidiq, Mohamad,2010. "Penerapan Analisis SWOT Guna Penyusunan Rencana Induk E-Government Kabupaten Kaur", Jurnal Teknologi Informasi, Vol, 6, No. 1, pp 80-93

Jen-Yao, Chung. Xiang Fei. 2015. IT For Future E-Business Management, Information Systems and e-Business Management, Volume 13, Issue 2, pp 191-192

Koilam, Regina a, 2010. Pembuatan Perencanaan Strategis Sistem Informasi Dengan Metode Analisa SWOT dan BSC Untuk Meningkatkan Daya Saing di PT
XYZ Untuk Tahun 2010-2015, Tesis Magister Managemen Teknologi, Institut Teknologi Sepuluh Nopember, Surabaya.

Narasipuram. Murali Mohan.2004. Modeling Framework for EBusiness Systems,Digital Communities In a Networked Society, Vol 139, pp 357-366

Nof. Shimon dan Ceroni. Jose. 2015. eLogistics, e-Production, and eSupply Networks._ Revolutionizing Collaboration through e-Work, eBusiness, and e-Service, Volume 2, pp 237-271.

Anonim. 2011. Panduan Logistic Indonesia, Penerbit PPM dan Asosiasi Logistic Indonesia.

Pujawan. I Nyoman. 2015.Supply Chain Management. Management Logistic. Volume 1, pp 288

Wijayanto. 2011. Sistem Informasi Managemen Produksi dan Pemasaran Pada Sistem Informasi Managemen Korporasi. Jurnal Teknologi Informasi, Volume 7 Nomor 1.

BPS, Volume Ekspor-Impor Indonesia, 2014. URL :

https://www.bps.go.id/linkTabelStatis/vie w/id/1003, 25 Maret 2016. 